\title{
JOURNAL ANALYSIS ON OPHTHALMOLOGY AND OTHERS
}

Análise dos periódicos da oftalmologia e outros

DenISE de Freitas

\begin{abstract}
A B S TR A C T
Objective: To update knowledge and methods to access and view the journals included in Qualis of CAPES Medicine III, and how to measure the impact factor. Method: Document review on the attempt to verify the way Qualis uses for ranking journals cited by the post-graduate programs of Medicine III in their evaluation periods, and the impact factors obtained by journals indexing base. Results: The classification is annual and are ranking in strata ranging from A1, the highest, and A2; B1; B2; B3; B4; B5; C. The latter has zero evaluation weight. These strata take as reference the impact factor of the journals listed by the programs. The same journal can be classified into different Qualis in other areas, and this is no inconsistency, but expressed the assigned value, in each area, at that particular journal. The Impact Factor is measured using the Journal of Citation Report in Web of Knowledge website. Conclusion: Using the criteria established by WebQualis for stratification of journals there is a quality guidance of what is produced by the program and, based on it, can be made scientific comparison of program performance. Consulting the JCR is recommended because it defines exactly what is the journal's impact factor; Qualis stratifies numerical intervals and not individual journal specificity.
\end{abstract}

Key Words: Impact factor. Educational Measurement. Ophtalmology.

\section{INTRODUCTION}

The Qualis is a tool used by Capes for stratification of scientific journals that post-graduate programs (PPG) uses for publication. The classification of these journals is divided by area of assessment, in this case, Medicine III or PPG surgical area. The Qualis is designed to meet the specific needs of the PPG evaluation system by CAPES and is based on information provided by the Data Collection/Sucupira Platform.

The objective of this review is to update the knowledge of the means and methods to access and view the journals of the Qualis of Medicine III of CAPES.

\section{METHODS}

Consultation was done on the intellectual production classification held in Qualis Periodicals available in http://www.capes. gov.br/avaliacao/instrumentos-de-apoio/classificacao-da-producao-intelectual" and "Journal of Citation Report (JCR) "(ISI Web of Knowledge, Thomson Reuters available inhttp://admin-apps-webofknowledge.ez69.periodicos.capes.gov.br/JCR/ JCR?RQ=LIST_SUMMARY_JOURNAL\&Cursor $=41^{2}$, both accessed on March 22, 2015.

Special attempt was to analyze the way used by Qualis for ranking journals listed by all Medicine III post-graduate programs in their evaluation periods, and the impact factors obtained by the journals.

\section{RESULT}

Classification undergoes annual update process, stratified from $A 1$, the highest, to $A 2 ; B 1 ; B 2 ; B 3 ; B 4 ; B 5 ; C$. The latter has zero weight in the evaluation process. The same journal can be classified into different Qualis in other areas, and this is no inconsistency, but expressed the assigned value in each area that one particular journal has. As CAPES points out, it is not the intention with this rating - that is specific to the process of evaluation of each area - to set the absolute quality of journals. The browser to access the classification and consulting Qualis areas, as well as disclosure of the criteria used for the journals classification, is named WebQualis. It can be accessed by going to the home web page of CAPES portal and choosing "Nossas Ações" by "Avaliação" page (Figure 1). Once on this page, in the end, there is a "link" to access the WebQualis (Figure 2).

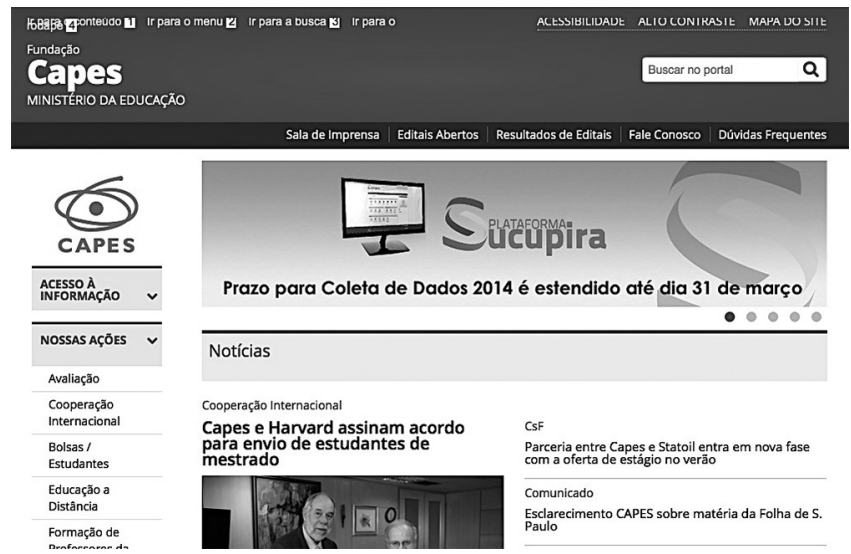

FIGURE 1 - CAPES electronic site with the homepage where there is access to "Nossas Ações"

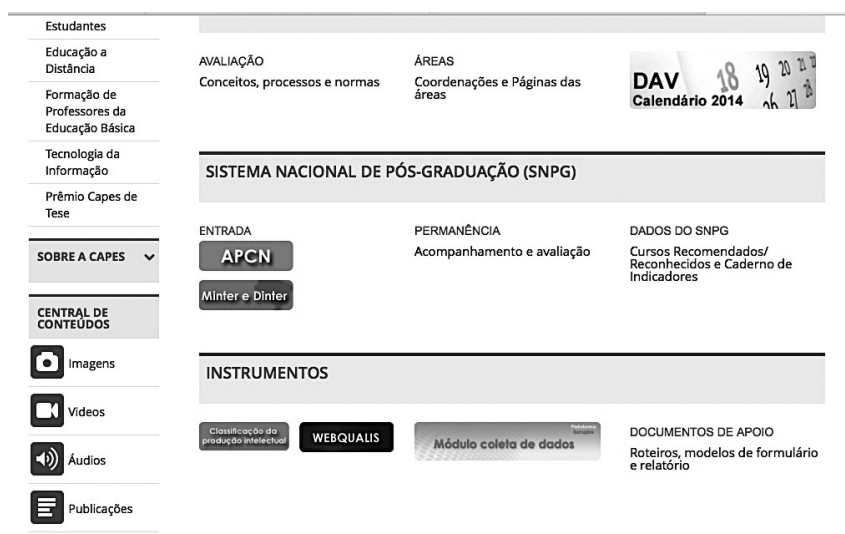

FIGURE 2 - CAPES electronic site with the homepage where, at the end, there is a "link" to access the WebQualis

Once in WebQualis page will be found on the far right "Consultar" with the options of "Classificação" or "Critérios Qualis por área". In the latter, there is access to the document that explains the criteria of the area, in this case Medicine III, for the classification of journals. Once in the "Classificação" page, it can be consulted the journal for its ISSN, title, by rating/assessment area (journals $A 1, A 2$, etc.) or access to the full list of all journals.

Qualis does not provide only medical journals, because researchers must be open to the possibility of publish in journals that do not fall within the medical field. Still, it does not provide the specific impact factor of each journal. For this,

From the Programa de Pós-Graduação em Oftalmologia e Ciências Visuais da Universidade Federal de São Paulo - UNIFESP (Post-Graduate Program in Ophthalmology and Visual Sciences, Federal University of São Paulo), São Paulo, SP, Brazil 
data not covered by the Qualis can be found on database "Journal of Citation Report (JCR)" (ISI Web of Knowledge, Thomson Reuters).

To access the JCR and to know the journals impact factor, must enter Portal de Periódicos CAPES/MEC, and the sector "Busca" to access the "Buscar Base" page. Once in the JCR (Figure 3) in the left option ("Select the JCR edition and year") should be noted in the "JCR Science Edition" the year wanted to be searched, the most recent is 2013. To the right are the options "View the group of journals by", "Search for a specific journal" or "View all journals". To get journals in specifc area should be accessed "View the group of journals by" and in it choose the "subject category", in this case Ophthalmology (Figure 4).

\begin{tabular}{|c|c|}
\hline Select a JCR edition and year: & Select an option: \\
\hline $\begin{array}{l}\text { - JCR Science Edition } 2013 \text {, } \\
\text { JCR Social Sciences Edition } 2013 \text {, }\end{array}$ & $\begin{array}{l}\text { View a group of journals by Subject Category } \\
\text { Search for a specific journal } \\
\text { View all journals }\end{array}$ \\
\hline \multicolumn{2}{|c|}{ Submit } \\
\hline
\end{tabular}

FIGURE 3 - Electronic site of "Journal of Citation Report (JCR)" (ISI Web of Knowledge, Thomson Reuters) in which, the option on left "JCR Science Edition" should mark the year wanted to be searched. On the right should be chosen "View the group of journals by"

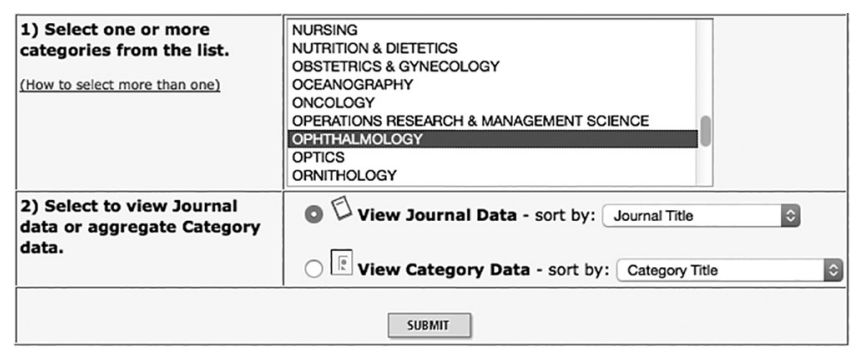

FIGURE 4 - Electronic site of the JCR with the chosen Ophthalmology journals in the "View the group of journals by"

Once entering the Ophthalmology page can be arranged scientific journals for various items (journal title, total citations, etc.); in this case chooses the "impact factor" (Figure 5).

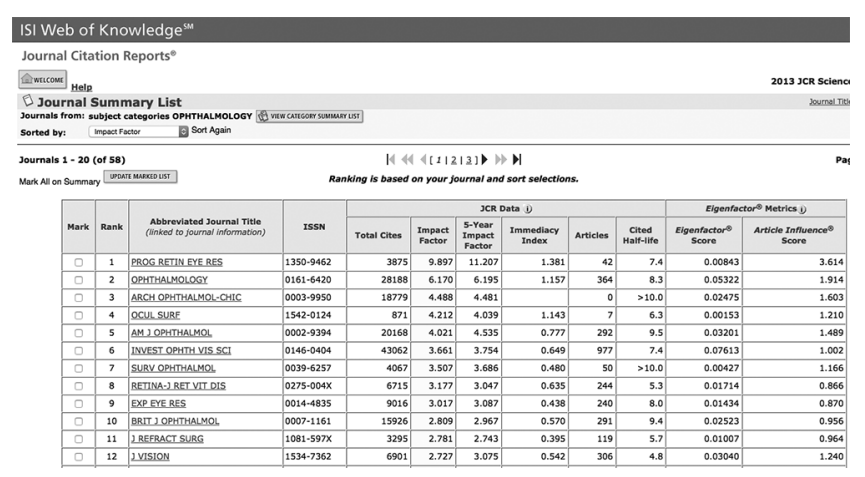

FIGURE 5 - JCR site with journals arranged by Impact Factor

Currently the JCR list 58 specific scientific journals in the area of Ophthalmology. If the impact factors of them are analyzed by the average, obtains 2.109 and with the median 1.801. The journal with highest impact factor is 9.897 ("Progress in Retinal and Eye Research") and the lowest is 0.163 (Brazilian Journal of Ophthalmology). Stratification of journals in WebQualis for Medicine III in the 2010-2012 period was determined as: $A 1 \geq 4$; $A 2 \geq 2,85$; $B 1 \geq 1,6$; $B 2 \geq 0,8$; $B 3$ $\geq 0.01$; B4 journals cited in Medline, SciELO, Lilac; B5 journals cited in other bases. Focusing on Ophthalmology journals cited by JCR can be inferred that, by the year 2013 - the last year this base was updated - WebQualis $A 1$ has the possibility of publishing in six journals; $A 2$ in four; $B 1$, in 23; $B 2$, in $18, B 3$ in seven journals (Table 1).
TABLE 1 - Journals listed in the "Journal of Citation Report (JCR)" (ISI Web of Knowledge, Thomson Reuters) classified by Qualis and Impact Factor

\begin{tabular}{|c|c|c|c|c|c|}
\hline Rank & Qua & Abbreviated Journal Title & ISSN & $\begin{array}{l}\text { Impact } \\
\text { Factor }\end{array}$ & $5 y$ Impact \\
\hline 1 & A1 & PROG RETIN EYE RES & $1350-9462$ & 9.897 & 11.207 \\
\hline 2 & A1 & OPHTHALMOLOGY & $0161-6420$ & 6.17 & 6.195 \\
\hline 3 & A1 & JAMA OPHTHALMOL & $2168-6165$ & 4.49 & \\
\hline 4 & A1 & ARCH OPHTHALMOL & 0003-9950 & 4.488 & 4.481 \\
\hline 5 & A1 & OCUL SURF & $1542-0124$ & 4.212 & 4.039 \\
\hline 6 & A1 & AM J OPHTHALMOL & 0002-9394 & 4.021 & 4.535 \\
\hline 7 & A2 & INVEST OPHTH VIS SCI & 0146-0404 & 3.661 & 3.754 \\
\hline 8 & A2 & SURV OPHTHALMOL & 0039-6257 & 3.507 & 3.686 \\
\hline 9 & A2 & RETINA-J RET VIT DIS & $0275-004 X$ & 3.177 & 3.047 \\
\hline 10 & A2 & EXP EYE RES & $0014-4835$ & 3.017 & 3.087 \\
\hline 11 & B1 & BRIT J OPHTHALMOL & 0007-1161 & 2.809 & 2.967 \\
\hline 12 & B1 & J REFRACT SURG & $1081-597 X$ & 2.781 & 2.743 \\
\hline 13 & B1 & J VISION & $1534-7362$ & 2.727 & 3.075 \\
\hline 14 & B1 & OPHTHAL PHYSL OPT & 0275-5408 & 2.664 & 1.743 \\
\hline 15 & B1 & CURR OPIN OPHTHALMOL & $1040-8738$ & 2.638 & 2.704 \\
\hline 16 & B1 & J CATARACT REFR SURG & 0886-3350 & 2.552 & 2.766 \\
\hline 17 & B1 & ACTA OPHTHALMOL & $1755-375 x$ & 2.512 & 2.538 \\
\hline 18 & B1 & J GLAUCOMA & $1057-0829$ & 2.427 & 2.297 \\
\hline 19 & B1 & VISIO & 0042 & 2.381 & 2.551 \\
\hline 20 & B1 & COR & 027 & 2.36 & 2.239 \\
\hline 21 & B1 & GRA & $32 x$ & 2.333 & 2.274 \\
\hline 22 & B1 & MOL VIS & $1090-0535$ & 2.245 & 2.433 \\
\hline 23 & B1 & OPTOMETRY VISION SCI & $1040-5488$ & 2.038 & 2.331 \\
\hline 24 & B1 & LENS ANTERIO & $1367-0484$ & 2 & \\
\hline 25 & B1 & HALMOL & $1442-6404$ & 1.953 & 2.158 \\
\hline 26 & B1 & $\mathrm{JO}$ & 2090-004X & 1.935 & 1.852 \\
\hline 27 & B1 & EYE & $0950-222 x$ & 1.897 & 1.943 \\
\hline 28 & B1 & OPHTHALMOLOGICA & $0030-3755$ & 1.867 & 1.454 \\
\hline 29 & B1 & LMOL & 022 & 1.807 & 1.504 \\
\hline 30 & B1 & $\mathrm{OL}$ & 002 & 1.795 & 1.587 \\
\hline 31 & B1 & EYE CONTACT LENS & $1542-2321$ & 1.679 & 1.92 \\
\hline 32 & B1 & VISUAL NEUROSCI & $0952-5238$ & 1.676 & 1.705 \\
\hline 33 & B1 & CURR EYE RES & $0271-3683$ & 1.663 & 1.751 \\
\hline 34 & B2 & LAMM & 09 & 1.44 & 1.381 \\
\hline 35 & B2 & MACOL TH & $1080-7683$ & 1.42 & 1.467 \\
\hline 36 & B2 & OPHTHALMIC RES & 0030-3747 & 1.376 & 1.312 \\
\hline 37 & B2 & OPTOMETRY & 1529-1839 & 1.339 & 1.399 \\
\hline 38 & B2 & SURG LAS IM & $1542-8877$ & 1.318 & 1.088 \\
\hline 39 & B2 & & 000 & 1.299 & 1.568 \\
\hline 40 & B2 & MIOL & 0928 & 1.271 & 1.794 \\
\hline 41 & B2 & CLIN EXP OPTOM & 0816-4622 & 1.256 & 1.255 \\
\hline 42 & B2 & OPHTHALMIC GENET & $1381-6810$ & 1.233 & 1.225 \\
\hline 43 & B2 & SEMIN OPHTHALMOL & 0882-0538 & 1.196 & \\
\hline 44 & B2 & & 1091 & 1.142 & 1.25 \\
\hline 45 & B2 & DO & 486 & 1.108 & 1.798 \\
\hline 46 & B2 & BMC OPHTHALMOL & $1471-2415$ & 1.075 & 1.52 \\
\hline 47 & B2 & EUR J OPHTHALMOL & $1120-6721$ & 1.058 & 1.006 \\
\hline 48 & B2 & JT RES & 8692 & 1.056 & 1.427 \\
\hline 49 & B2 & LMOL & 4738 & 0.927 & 0.98 \\
\hline 50 & B2 & OCUL TOXICOL & $1556-9527$ & 0.92 & 0.987 \\
\hline 51 & B2 & OPHTHAL PLAST RECONS & 0740-9303 & 0.914 & 0.895 \\
\hline 52 & B3 & J PEDIAT OPHTH STRAB & 0191-3913 & 0.731 & 0.868 \\
\hline 53 & B3 & OPHTH & 0941 & 0.719 & 0.67 \\
\hline 54 & B3 & KLIN MONATSBL AUGENH & $0023-2165$ & 0.665 & 0.526 \\
\hline 55 & B3 & INT J OPHTHALMOL & 2222-3959 & 0.5 & 0.302 \\
\hline 56 & B3 & ARQ BRAS OFTALMOL & 0004-2749 & 0.44 & 0.518 \\
\hline 57 & B3 & J FR OPHTALMOL & $0181-5512$ & 0.361 & 0.455 \\
\hline & & & $0034-$ & & \\
\hline
\end{tabular}

\section{DISCUSSION}

Using the criteria established by WebQualis as guidance for stratification of journals that the areas use in the periodic evaluations, it is possible to quantify what is produced in the programs and, based on it, can be made scientific comparisons in post-graduate programs performance. In additional purpose, JCR consultation offers exactly what is the journal's impact factor, as far as Qualis stratifies numerical intervals but not individual journal specificity.

These two consultations together give security to the program, and the possibility to quantify himself the quality of what was produced scientifically. 


\section{RESUMO}

Objetivo: Atualização do conhecimento dos meios e métodos de acessar e visualizar os periódicos do Qualis da Medicina III da CAPES e a mensuração do Fator de Impacto. Método: Buscou-se verificar a forma utilizada pelo Qualis para classificar os periódicos referidos pelos programas de pós-graduação da Medicina III em seus períodos de avaliação e os fatores de impacto obtidos pelas revistas em base indexadora. Resultados: A classificação é anual e são enquadrados em estratos que variam de A1, o mais elevado, a A2; B1; B2; B3; B4; B5; C. Este último tem peso zero. Esses estratos levam como referência o Fator de Impacto dos periódicos referidos pelos programas. Um mesmo periódico pode ter classificação em Qualis diferentes em outras áreas, e isto não constitui inconsistência, mas expressa o valor atribuído, em cada área, àquela determinada revista científica. O Fator de Impacto é mensurado navegando-se no site do Journal of Citation Report da Web of Knowledge. Conclusão: A utilização dos critérios estabelecidos pelo WebQualis para estratificação dos periódicos é norteadora da qualidade do que se produz nos programas e, com base nela, pode-se fazer comparações de desempenho científico. Já a consulta ao JCR é complementarmente adequada de ser feita porque define com exatidão qual é o fator de impacto da revista, em função de que o Qualis estratifica faixas numéricas e não especificidade individual do periódico.

Descritores: Avaliação educacional. Fator de impacto. Oftamologia.

\section{REFERENCES}

1. Classificação da produção intelectual. Qualis-Periódicos. Disponível em: http://www.capes.gov.br/avaliacao/instrumentos-de-apoio/ classificacao-da-producao-intelectual.

2. Journal of Citation Report (JCR) (ISI Web of Knowledge, Thomson Reuters). Disponível em: http://admin-apps-webofknowledge. ez69.periodicos.capes.gov.br/JCR/JCR?RQ=LIST_SUMMARY_JOURNAL\&cursor $=41$
Recebido em: 19/02/2015

Aceito para publicação em: 12/09/2015

Conflito de interesses: nenhum

Fonte de financiamento: nenhum

Endereço para correspondência:

Denise de Freitas

dfreitas@uol.com.br 